\title{
PRESJEK STANJA COVID-19 PANDEMIJE U ZAPADNOHERCEGOVAČKOJ ŽUPANIJI
}

\author{
Ana Bakula', Ivana Čović́, Marija Šantić', Katarina Herceg' \\ ${ }^{1}$ Fakultet zdravstvenih studija Sveučilišta u Mostaru, 88000 Mostar, BiH
}

\section{SAŽETAK}

UVOD: Od prvog slučaja u Kini, teški akutni respiratorni sindrom koronavirus 2 (SARS-CoV-2) proširio se širom svijeta, a Svjetska zdravstvena organizacija proglasila ga je pandemijom.

U Zapadnohercegovačkoj županiji prvi slučaj zabilježen je 23. ožujka 2020. godine.

CILJ: Prikazati učestalost COVID-19 bolesti u Zapadnohercegovačkoj županiji (ZHŽ) u vremenskom razdoblju 01. 08. 2020. - 01. 11. 2020.

ISPITANICI I METODE: U radu je prikazana učestalost COVID-19 infekcije u ZHŽ, u razdoblju 01. 08. 2020. - 01. 11. 2020. godine. Korišteni podaci obrađivani su u Zavodu za javno zdravstvo Zapadnohercegovačke županije (ZZJZ ZHŽ), isti su uzeti s platforme Zavoda za javno zdravstvo Federacije Bosne i Hercegovine (FBiH). Prikazani su podaci pozitivnih pacijenata kojima je prisutnost virusa dokazana rt-PCR testom na Zavodu za mikrobiologiju i labaratorijsku dijagnostiku Sveučilišne kliničke bolnice Mostar.

REZULTATI: U ZHŽ u kolovozu 2020. godine bilo je ukupno 568 potvrđenih slučajeva zaraze COVID-19 bolesti, u rujnu njih ukupno 746, dok je u listopadu bilo ukupno 890 potvrđenih slučajeva. Najviše oboljelih bilo je u općini Široki Brijeg, ujedno je i najveća po broju stanovnika u odnosu na ostale tri koje čine ZHŽ. Primjenom Hi-kvadrat testa utvrđena je razlika u broju oboljelih s obzirom na spol u kolovozu, pri čemu je bilo zaraženo više muškaraca COVID-19 infekcijom. Nadalje primjenom Hi-kvadrat testa nije utvrđena statistički značajna razlika s obzirom na spol u rujnu i listopadu. U kolovozu je zbog posljedica zaraze COVID-19 infekcijom umrlo ukupno 9 oboljelih, u rujnu 11 oboljelih, a u listopadu njih 15 , pri čemu je stopa smrtnosti za ova tri mjeseca iznosila $1,58 \%$.

ZAKLJUČAK: U odnosu na dob imamo velik raspon godina, a pretežito obolijevaju osobe muškog spola. Stopa smrtnosti iznosila je 1, 58\%. Nakon 01. 11. 2020. broj zaraženih i umrlih nastavlja rasti.

Ključne riječi: koronavirus; covid-19; SARS-CoV-2; pandemija

Osoba za razmjenu informacija: mag. fiziot. Ana Bakula

E-mail: anaabakula@gmail.com 


\section{UVOD}

Novi koronavirus otkriven je 7. siječnja 2020. godine (ozbiljan akutni respiratorni sindrom koronavirus 2, SARS CoV2) kao mogući uzrok teške pneumonije u kineskom gradu Wuhanu (1). Prijenos s osobe na osobu postao je epidemiološki najvažniji put širenja infekcije. Širenje bolesti u Europi i drugimdijelovima svijetaprvenstveno je uzrokovano kapljičnim prijenosom s čovjeka na čovjeka. Osim prijenosa s bolesnih ljudi, moguće je prenošenje virusa i s asimptomatskih bolesnika (2). Inkubacijsko razdoblje, vrijeme između izlaganja virusu i pojave prvih znakova i simptoma oboljenja, iznosi 2 do 14 dana, odnosno prosječno 5 dana (3), (4). Medijan vremena od pojave simptoma do prvog prijema u bolnicu bio je 7,0 - 9,0 dana, dok su simptomi infekcije COVID-19 pojavljuju se nakon razdoblja inkubacije od otprilike 5,2 dana (5).Razdoblje od pojave simptoma COVID-19 do smrti bolesnika, kretalo se u rasponu od 6 do 41 dana, s medijanom od 14 dana. To razdoblje ovisi o dobi bolesnika i statusu bolesnikovog imunološkog sustava. Razdoblje je bilo i kraće među bolesnicima starijima od 70 godina u usporedbi s onima mlađima od 70 godina(6). Bolest se u ranijim fazama predstavljala prvenstveno kao respiratorna bolest $\mathrm{s}$ većim morbiditetom i smrtnošću kod starijih osoba (7). Do danas je većina dostupne literature usmjerena na odraslu populaciju ostavljajući primjetnu prazninu u opisu dječjeg COVID-19 (8). Djeca svih dobnih skupina izložena su riziku od infekcije SARS-CoV-2 virusom i ozbiljnih manifestacija bolesti (9).Izvještaji iz epidemijskih žarišta ukazuju da je starija životna dob značajan faktor rizika zanepovoljne ishode uključujući povećanu stopu mortaliteta (10), (11). U ovom radu prikazana jeučestalost COVID-19 infekcije u ZHŽ, $\mathrm{BiH}$ u razdoblju 01. 08. 2020. - 01. 11. 2020. godine.

\section{ISPITANICI I METODE}

U članku je prikazano kretanje i širenje COVID-19 bolesti u ZHŽ. Za istraživanje su korišteni podaci Zavoda za javno zdravstvo Županije Zapadnohercegovačke, zaključno s 01. studenog 2020. godine. Podaci korišteni u ovom istraživanju prikupljani su na internetskoj platformi SZO te podatci
ZZJZ ŽZH. Prikazani su podaci pozitivnih pacijenata kojima je prisutnost virusa dokazana rt-PCR testom na Zavodu za mikrobiologiju i labaratorijsku dijagnostiku Sveučilišne kliničke bolnice Mostar.

$\mathrm{Za}$ analizu nominalnih varijabli korišten je $\chi^{2}$ test. Mogućnost pogreške prihvatila se pri $\alpha<0,05$ te su razlike između skupina bile prihvaćene kao statistički značajne za $\mathrm{P}<0,05$. $\mathrm{P}$ vrijednosti koje se nisu mogleiskazati do najviše tri decimalna mjesta, prikazane su kao $\mathrm{P}<0,001$. Za obradu i analizu podataka koristio se programski sustav SPSS for Windows (inačica 20. 0, SPSS Inc, Chicago, Illinois, SAD).

\section{REZULTATI}

U ŽZH u kolovozu 2020. godine bilo je ukupno 568 potvrđenih slučajeva zaraze COVID-19 infekcijom, u rujnu njih ukupno 746, dok je u listopadu bilo ukupno 890 potvrđenih slučajeva. Primjenom Hi-kvadrat testa utvrđena je statistički značajna razlika u broju oboljelih, pri čemu se broj oboljelih povećavao $\left(x^{2}=70,86 ; \mathrm{p}<0,05\right)($ Graf 1 . $)$.

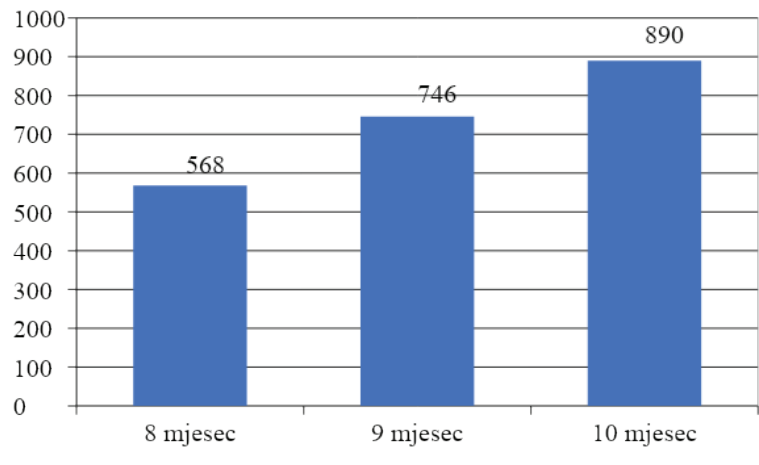

Graf 1. Ukupan broj potvrđenih slučajeva zaraze COVID-19 infekcijom u ŽZH u 8., 9. i 10. mjesecu 2020. godine

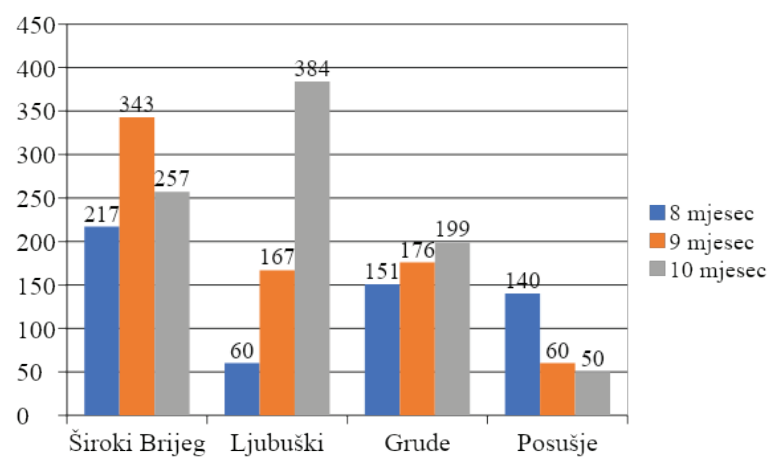

Graf 2. Potvrđeni slučajevi zaraze COVID-19 infekcijom u ŽZH po općinama u 8., 9. i 10. mjesecu 2020. godine 
Primjenom Hi-kvadrat testa utvrđena je statistički značajna razlika u broju oboljelih u ŽZH po općinama, pri čemu je najviše oboljelih bilo u Širokom Brijegu $\left(x^{2}=300,8 ; p<0,05\right)($ Graf 2. $)$.

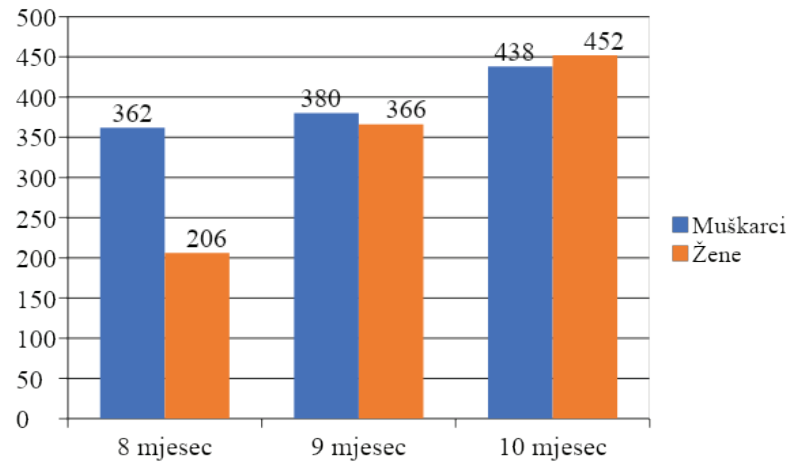

Graf 3. Spolna struktura osoba zaraženih COVID-19 infekcijomu ŽZH u 8., 9. i 10. mjesecu 2020. godine

Primjenom Hi-kvadrat testa utvrđena je razlika u broju oboljelih s obzirom na spol u 8 mjesecu, pri čemu je više muškaraca bilo zaraženo COVID-19 infekcijom $\left(\mathrm{x}^{2}=42,8 ; \mathrm{p}<0,05\right)$. Nadalje primjenom Hi-kvadrat testa nije utvrđena statistički značajna razlika s obzirom na spol u 9 mjesecu $\left(x^{2}=0,27 ; p>0\right.$, 05) i 10 mjesecu $\left(x^{2}=0,22 ; p>0,05\right)(G r a f 3$. ).

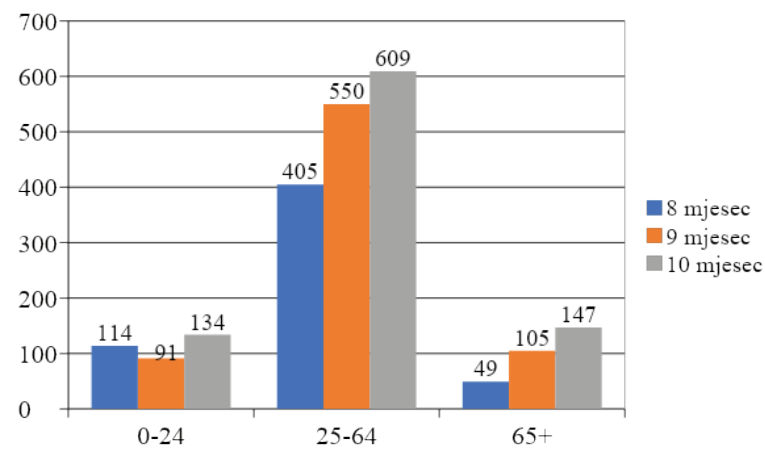

Graf 4. Dobna struktura osoba zaraženih COVID-19 infekcijom u ŽZH u 8., 9. i 10. mjesecu 2020. godine

Primjenom Hi-kvadrat testa utvrđena je razlika u broju oboljelih s obzirom na dob u, pri čemu je najveći broj oboljelih u svim promatranim mjesecima imao od 25 do 64 godine $\left(\mathrm{x}^{2}=30,4 ; \mathrm{p}<0,05\right)$ (Graf 4. ).

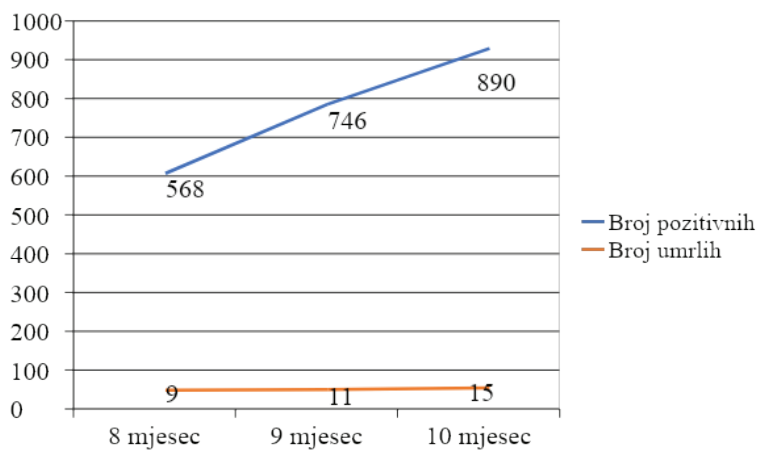

Graf 5. Prikaz broja oboljelih i broja umrlih od COVID-19 infekcijeu ŽZH u 8., 9. i 10. mjesecu 2020. godine

U kolovozu je zbog posljedica zaraze virusom COVID-19 umrlo ukupno 9 oboljelih, u rujnu 11 oboljelih, a u listopadu njih 15, pri čemu je stopa smrtnosti za ova tri mjeseca iznosila 1, 58\% (Graf 5.).

\section{RASPRAVA}

Prvi slučaj bolesti novog koronavirusa u Republici Hrvatskoj otkriven je 26. veljače 2020. godine, a Srbija je izvijestila o prvom slučaju bolesti COVID-19 6. ožujka 2020. godine (12), (13). Italija je svoj prvi slučaj COVID-19 bolesti otkrila 21. veljače 2020., ali samo dva dana kasnije Italija je izbrojala ukupno 113 slučajeva COVID-19 (14). U ŽZZH prvi potvrđeni slučaj otkriven je 23. 03. 2020. godine. Prema podacima dostavljenim Zavodu za javno zdravstvo FBiH, zaključno s 30. 10. 2020. u 12 sati registrirano je 30603 laboratorijski potvrđenih slučajeva COVID-19 bolesti i 777 smrtnih slučajeva povezanih s COVID-19. Unutar FBiH većim dijelom su bile zaražene žene, dok druge studije pokazuju veći broj muškaraca, kao što je slučaj u ŽZZH(15), (16). U ŽZH uočeno je statistički značajno povećanje broja oboljelih u listopadu u odnosu na kolovoz. Dolazak jeseni i ulaskom u period kada se stanovništvo više okuplja u zatvorenim prostorima, kao i povratak u školske ustanove dovodi do očekivanog povećanja širenja epidemije (5). Broj umrlih u ukupnom broju oboljelih je za djecu oko $0,1 \%$, što je značajno manje nego u odraslih (2,3\%) (17). Pregled 45 radova pokazao je da djeca obuhvaćaju 1-5\% COVID-19 slučajeva i da imaju blažu bolest koja iznimno završava smrću (18). U Sjedinjenim Američkim Dr- 
žavama (SAD-u) 5\% COVID-19 slučajeva (i manje od $1 \%$ od ukupnog broja hospitaliziranih) čine djeca (19). U ŽZH najveći broj oboljelih imao je od 25 do 64 godine što se slaže s objavljenim studijama (20), (21). SAD prema provedenom istraživanju o smrtnim slučajevima u bolnici bilježi oko $3,3 \%$ ili manje smrtnih slučajeva kod pacijenata u dobi od 40 ili manje godina, $4,8 \%$ smrtnih slučajeva među pacijentima u 50-ima, 6,4\% smrtnih slučajeva u 60-ima, $12,6 \%$ smrtnih slučajeva u 70 -ima i $25,9 \%$ smrtnih slučajeva u 80-im godinama života (22). U Lombardiji u Italiji stopa smrtnosti i apsolutni mortalitet bili su visoki. Zaključeno s 30. svibnja 2020. godine ukupno je 915 pacijenata $(53,4 \%)$ umrlo u bolnici (23). U ŽZHstopa smrtnosti za ova tri mjeseca iznosila je 1,58 \%. U ŽZH zabilježeno je 726 pozitivnih osoba mlađih od 24 godine. Dana 9. travnja 2020., mjesec dana nakon što je COVID-19 prvi put otkriven u Bosni i Hercegovini, WHO je Bosnu i Hercegovinu klasificirala kao zemlju koja ima potencijal za prijenos u zajednicu nakon što je zabilježeno 816 slučajeva COVID-19 i 35 smrtnih slučajeva(24). Sada se javljaju zabrinutosti zbog mentalnog zdravlja, psihološke prilagodbe i oporavka zdravstvenih radnika koji liječe i njeguju pacijente s COVID-19(25). Pandemija koronavirusom za veliku većinu osoba predstavlja stresnu situaciju razine velikog stresnog doživljaja u kojoj može biti ugroženo zdravlje čitave populacije. Ugroženo je i zdravlje osoba koje sudjeluju u liječenju zaraženih osoba. Stanje nepovoljnog odgovora na teški stres pogoduje pojavi duševnih i tjelesnih bolesti i značajno otežava socijalno funkcioniranje. Stoga je nužno uključiti psihosocijalnu podršku i brigu za duševno zdravlje u zajedničku prevenciju i kontrolu epidemiološke situacije od samih početaka epidemije/pandemije (26). Tijekom pandemije COVID-19 u BiH, sve psihijatrijske službe funkcionirale su u smanjenom opsegu, pridržavajući se mjera zaštite i samozaštite osoblja i korisnika usluga (27).

\section{ZAKLJUČAK}

U odnosu na dob imamo velik raspon godina, a pretežito obolijevaju osobe muškog spola. Stopa smrtnosti iznosila je 1, 58\%. Za kontrolu trenutne epidemije potrebne su opsežne mjere za smanjenje prijenosa COVID-19 od osobe do osobe. Bosna i Hercegovina spada u nerazvijene države svijeta, analogno s tim ima problem manjka kapaciteta adekvatnih zdravstvenih ustanova i osoblja. Stoga se poseban naglasak i napori ulažu na zaštitu i/ili smanjenju prijenosa u osjetliivoj populaciji, uključujući starije, imunokompromirirane osobe, osobe sa kroničnim bolestima i zdravstvene djelatnike. Nakon 01. 11. 2020. broj zaraženih i umrlih nastavlja rasti.

\section{LITERATURA}

1. Bernard Stoecklin S, Rolland P, Silue Y, Mailles A, Campese C, Simondon A, et al. First cases of coronavirus disease 2019 (COVID-19) in France: surveillance, investigations and control measures, January 2020. Euro Surveill Bull Eur Sur Mal Transm Eur Commun Dis Bull. 2020 Feb; 25(6).

2. Koo JR, Cook AR, Park M, Sun Y, Sun H, Lim JT, et al. Interventions to mitigate early spread of SARS-CoV-2 in Singapore: a modelling study. Lancet Infect Dis [Internet]. 2020 Jun 1 [cited 2021 Apr 25]; 20(6): 678-88. Available from: https: //www. thelancet. com/journals/ laninf/article/PIIS1473-3099(20)30162-6/abstract

3. Yang L, Dai J, Zhao J, Wang Y, Deng P, Wang J. Estimation of incubation period and serial interval of COVID-19: analysis of 178 cases and 131 transmission chains in Hubei province, China. Epidemiol Infect [Internet]. 2020 Jun 19 [cited 2021 Apr 25]; 148. Available from: https: //www. ncbi. nlm. nih. gov/ pmc/articles/PMC7324649/

4. Hukic M, Ponjavic M, Tahirovic E, Karabegovic A, Ferhatbegovic E, Travar M, et al. SARSCoV-2 virus outbreak and the emergency public health measures in Bosnia and Herzegovina: January - July, 2020. Bosn J Basic Med Sci. 2021 Feb 1; 21(1): 111-6.

5. Li Q, Guan X, Wu P, Wang X, Zhou L, Tong $\mathrm{Y}$, et al. Early Transmission Dynamics in Wuhan, China, of Novel Coronavirus-Infected Pneumonia. N Engl J Med [Internet]. 2020 Mar 26 [cited 2021 Apr 25]; 382(13): 1199207. Available from: https: //doi. org/10. 
Bakula A, Čović I, Šantić M, Herceg K. Presjek stanja covid-19 pandemije u Zapadnohercegovačkoj županiji. Zdravstveni glasnik. 2021;7(1): 63-69.

1056/NEJMoa2001316

6. Vasilj I, Ljevak I. EPIDEMIOLOŠKE KARAKTERISTIKE COVID-A 19. Zdr Glas [Internet]. 2020 May 29 [cited 2021 Apr 28]; 6(1): 9-18. Available from: https: //hrcak. srce. $\mathrm{hr} / 238970$

7. Bennett $S$, Tafuro J, Mayer J, Darlington D, Wong CW, Muntean E-A, et al. Clinical features and outcomes of adults with coronavirus disease 2019: A systematic review and pooled analysis of the literature. Int J Clin Pract. 2020 Sep 23; e13725.

8. Toba N, Gupta S, Ali AY, ElSaban M, Khamis AH, Ho SB, et al. COVID-19 under 19: A meta-analysis. Pediatr Pulmonol. 2021 Feb 25;

9. Kamidani S, Rostad CA, Anderson EJ. COVID-19 vaccine development: a pediatric perspective. Curr Opin Pediatr. 2021 Feb 1; 33(1): 144-51.

10. Zhang C, Gu J, Chen Q, Deng N, Li J, Huang $\mathrm{L}$, et al. Clinical and epidemiological characteristics of pediatric SARS-CoV-2 infections in China: A multicenter case series. PLOS Med [Internet]. 2020 Jun 16 [cited 2021 Apr 25]; 17(6): e1003130. Available from: https: //journals. plos. org/plosmedicine/article?id=10. 1371/journal. pmed. 1003130

11. Zhou F, Yu T, Du R, Fan G, Liu Y, Liu Z, et al. Clinical course and risk factors for mortality of adult inpatients with COVID-19 in Wuhan, China: a retrospective cohort study. Lancet Lond Engl. 2020 Mar 28; 395(10229): 1054-62.

12. Službena stranica Vlade za pravodobne i točne informacije o koronavirusu [Internet]. koronavirus. hr. [cited 2021 Apr 25]. Available from: https: //www. koronavirus. hr/

13. COVID-19 [Internet]. [cited 2021 Apr 25]. Available from: https: //www. srbija. gov. rs/ sekcija/en/151926/covid-19. php

14. Lazić N, Lazić V, Kolarić B. First three months of COVID-19 in Croatia, Slovenia, Serbia and Federation of Bosnia and Herzegovina - comparative assessment of disease control measures. Infektološki Glas [Internet]. 2020 Nov 12 [cited 2021 Apr 25]; 40(2): 43-9.
Available from: https: //hrcak. srce. hr/index. php?show=clanak\&id_clanak_jezik $=357330$

15. COVID-19 [Internet]. ZZJZ FBiH. 2020 [cited 2021 Apr 25]. Available from: https: // www. zzjzfbih. ba/covid-19/

16. Beigel JH, Tomashek KM, Dodd LE, Mehta AK, Zingman BS, Kalil AC, et al. Remdesivir for the Treatment of Covid-19 - Final Report. N Engl J Med [Internet]. 2020 Nov 5 [cited 2021 Apr 25]; 383(19): 1813-26. Available from: https: //doi. org/10. 1056/NEJMoa2007764

17. Xia W, Shao J, Guo Y, Peng X, Li Z, Hu D. Clinical and CT features in pediatric patients with COVID-19 infection: Different points from adults. Pediatr Pulmonol. 2020 May; 55(5): 1169-74.

18. Ludvigsson JF. Systematic review of COVID-19 in children shows milder cases and a better prognosis than adults. Acta Paediatr Oslo Nor 1992. 2020 Jun; 109(6): 1088-95.

19. CDCMMWR. Severe Outcomes Among Patients with Coronavirus Disease 2019 (COVID-19) - United States, February 12March 16, 2020. MMWR Morb Mortal Wkly Rep [Internet]. 2020 [cited 2021 Apr 25]; 69. Available from: https: //www. cdc. gov/ mmwr/volumes/69/wr/mm6912e2. htm

20. Chan JYK, Wong EWY, Lam W. Practical Aspects of Otolaryngologic Clinical Services During the 2019 Novel Coronavirus Epidemic: An Experience in Hong Kong. JAMA Otolaryngol-- Head Neck Surg. 2020 Jun 1; 146(6): 519-20.

21. Sorbello M, El-Boghdadly K, Di Giacinto I, Cataldo R, Esposito C, Falcetta S, et al. The Italian coronavirus disease 2019 outbreak: recommendations from clinical practice. Anaesthesia. 2020 Jun; 75(6): 724-32.

22. Richardson S, Hirsch JS, Narasimhan M, Crawford JM, McGinn T, Davidson KW, et al. Presenting Characteristics, Comorbidities, and Outcomes Among 5700 Patients Hospitalized With COVID-19 in the New York City Area. JAMA. 2020 May 26; 323(20): 2052-9.

23. Grasselli G, Greco M, Zanella A, Albano G, 
Antonelli M, Bellani G, et al. Risk Factors Associated With Mortality Among Patients With COVID-19 in Intensive Care Units in Lombardy, Italy. JAMA Intern Med. 2020 Oct 1; 180(10): 1345-55.

24. Arapović J, Skočibušić S. The first two months of the COVID-19 pandemic in Bosnia and Herzegovina: Single-center experience. Bosn J Basic Med Sci [Internet]. 2020 Aug 3; 20(3): 396-400. Available from: https: //www. bjbms. org/ojs/index. php/bjbms/article/view/4838

25. El-Hage W, Hingray C, Lemogne C, Yrondi A, Brunault P, Bienvenu T, et al. [Health professionals facing the coronavirus disease 2019 (COVID-19) pandemic: What are the mental health risks?]. L'Encephale. 2020 Jun; 46(3S): S73-80.

26. Babić D, Babić M. Kako se sačuvati od stresa za vrijeme pandemije koronom. Zdr Glas [Internet]. 2020 May 29 [cited 2021 Apr 28]; 6(1): 25-32. Available from: https: //hrcak. srce. $\mathrm{hr} / 239141$

27. Pajević I, Hasanović M, Avdibegović E, Džubur KA, Burgić RM, Babić D, et al. Organization of mental healthcare in Bosnia and Herzegovina during coronavirus disease 2019 pandemic. Indian J Psychiatry. 2020; 62(Suppl 3): S479-S491. Available from: https: //www. ncbi. nlm. nih. gov/pmc/articles/ PMC7659768/ 


\title{
OVERVIEW OF THE COVID-19 PANDEMIC IN THE WEST HERZEGOVINA CANTON
}

\author{
Ana Bakula', Ivana Čović́, Marija Šantić', Katarina Herceg' \\ ${ }^{1}$ Faculty of Health Studies University of Mostar, 88000 Mostar, B\&H
}

\begin{abstract}
Introduction: Since the first case in China, severe acute respiratory syndrome coronavirus 2 (SARS-CoV-2) has spread around the world, and the World Health Organization declared it a pandemic. The first case in the West Herzegovina Canton was recorded on March 23, 2020.

Objective: Provide an overview of the frequency of COVID-19 in the West Herzegovina Canton from July 1, 2020 to November 1, 2020.

Subjects and methods: The article presents the frequency of the COVID-19 infection in the West Herzegovina Canton from July 1, 2020 to November 1, 2020. The data were analyzed at the Institute for Public Health of the West Herzegovina Canton and were downloaded from the platform of the Institute for Public Health of the Federation of Bosnia and Herzegovina (FB\&H). The article presents data on patients who tested positive for COVID-19 verified by a RT-PCR test from the Department of Microbiology and Molecular Diagnosis of the University Clinical Hospital Mostar.

Results: In August 2020, there were a total of 568 confirmed cases of COVID-19 infection in the West Herzegovina Canton and a total of 746 cases in September, while in October there were a total of 890 confirmed cases. The highest number of patients was in the municipality of Široki Brijeg, and this is also the largest municipality in terms of population when compared to the other three that constitute the West Herzegovina Canton. Using the chi-square test, a difference was found in the number of patients according to gender in August, with more men being infected with the COVID-19 infection. In August, a total of 9 patients died from the COVID-19 infection, 11 in September, and 15 in October, the mortality rate for these three months was $1.58 \%$.

Conclusion: There was a great range in relation to age, and the incidence of the virus was greater in men. The mortality rate was 1. 58\%. The number of the infected and dead continues to rise after November 1, 2020.
\end{abstract}

Key words: coronavirus; Covid-19; SARS-CoV-2; pandemic

Correspondence: Ana Bakula, MPT

E-mail: anaabakula@gmail.com 